\title{
Conscientious Objections in Employment: is a duty of reasonable accommodation the answer?
}

\author{
LUCY VICKERS $^{1}$
}

Abstract:

This chapter considers how the law has dealt with requests for conscientious objection in the context of employment. Key cases for consideration include Ladele and McFarlane.

The chapter also considers whether a duty of accommodation, which is sometimes suggested as a way to manage religious interests in the work place, most recently by the think tank Res Publica, would be an effective mechanism to meet the religious freedom interests of those seeking exemption from workplace rules which affect their religious practice. The chapter suggests that a duty of reasonable accommodation is not the best way to address conscience claims at work, and that an approach based on indirect discrimination and proportionality should be preferred.

\section{Conscientious Objection in Employment: is a duty of reasonable accommodation the answer?}

The aim of this chapter is to consider how conscience claims are best addressed in the context of employment. The current mechanism for protecting those who raise conscience claims at work is through a non-discrimination claim under the Equality Act 2010. In what follows, the nondiscrimination model for managing conscience claims will be assessed, and its shortcomings identified. The chapter then asks whether basing claims on a duty of reasonable accommodation would improve the protection for those with conscientious objections to carrying out aspects of their jobs. By comparing the position in North America where such claims are dealt with under a duty of reasonable accommodation, the conclusion is reached that while this is an effective means of protection, it is not preferable to the indirect discrimination model. Instead, it is concluded that conscience claims can be adequately protected at work through the current legal framework.

\section{Conscientious objection and indirect Discrimination}

Requests to be exempt from carrying out work related tasks to which the claimant holds a conscientious objection ${ }^{2}$ are currently treated as cases of indirect discrimination, with the exception of special rules applying in the context of abortion and human embryology. ${ }^{3}$ Indirect discrimination is defined as the application of a provision, criterion or practice in relation to religion or belief which applies to those who do not share the religion or belief, but which puts or would put persons of the religion or belief in question at a particular disadvantage compared to others, and which cannot be

\footnotetext{
${ }^{1}$ For more on the issues discussed in this chapter, see chapters 6 and 7 of L Vickers, Religious Freedom, Religious Discrimination and the Workplace 2nd edn (Oxford, Hart Publishing, 2016).

${ }^{2}$ It is assumed in what follows that conscientious objections are based on religion or belief.

${ }^{3}$ Section 4(1) of the Abortion Act 1967 states: 'no person shall be under any duty ... to participate in treatment authorised by this Act to which he has a conscientious objection'. Similar terms can be found in Section 38 (1) Human Fertilisation and Embryology Act 1990.
} 
shown to be a proportionate means of achieving a legitimate aim. ${ }^{4} \mathrm{~A}$ neutral practice that is required of all staff but which puts persons who hold a conscientious objection ${ }^{5}$ to carrying out the task at a disadvantage compared with others would therefore give rise to a potential claim of indirect discrimination; any refusal to accommodate a request for exemption from the work task will therefore need to be justified. Cases have involved diverse matters, including objections to joining the rota for cleaning the office fridge,${ }^{6}$ and requests to be excused from offering a service to gay and lesbian clients. ${ }^{7}$ Other examples, which have been reported in the press, include requests from shop workers to be exempt from serving alcohol. ${ }^{8}$

The concept of indirect discrimination, with its requirement that any refusal to allow conscientious objection be justified, provides a flexible mechanism through which diverse claims can be assessed. Any assessment of proportionality will need to consider all the facts of the case, such as the ease with which others can be found to cover for the task without disadvantage or disruption to others, whether the individual can be redeployed to other duties, and how central the task is to the job in question. For example, exemption for a university lecturer from serving alcohol or meat products at a reception for new students would seem to be relatively simple to accommodate and so it would be unlikely for any refusal to be justified; the request does not relate to a core aspect of the job, and it will be relatively easy to find an alternative person to serve the refreshments. In contrast, it would be proportionate to refuse to accommodate a butcher who refused to handle meat, or a publican who refused to serve alcohol.

However, assessing proportionality is not always easy, and can involve careful deliberation on the part of the court to determine the correct balance between the interests of the employer in running an effective business and the religious interests of the member of staff with the conscience claim. An additional layer of complexity arises when the conscientious objection to a work related task has been on grounds which themselves are discriminatory against others. For example, cases involving marriage registrars who wish to be exempted from carrying out civil partnerships or same sex marriage; or involving staff who refuse to shake hands with clients of the opposite sex on religious grounds. These cases are treated as potentially indirectly discriminatory; the requirement to carry out the civil partnership or to shake hands with clients is a neutral requirement, which causes disadvantage to the particular religious employee because he or she cannot comply for religious reasons, and so the requirement will need to be justified as a proportionate means to achieve a legitimate aim.

Two cases have come before the UK courts where staff had conscientious objections to performing aspects of their jobs, for reasons which themselves involved discrimination on other

\footnotetext{
${ }^{4}$ Section 19 Equality Act 2010. The wording of the Directive is: 'where an apparently neutral provision, criterion or practice would put persons of a particular religion or belief . . . at a particular disadvantage compared with other persons' unless it can be justified: Art 2(2).

${ }^{5}$ While objections would not need to be religious they are likely to be linked to beliefs of a serious nature, such as to be classified as beliefs under the legislation. Less serious objections, of a type that would be unlikely to be classified as based on belief, are also unlikely to be classified as 'conscientious objections' either.

${ }^{6}$ Chatwal v Wandsworth Borough Council [2011] UKEAT 0487_10_0607

${ }^{7}$ Ladele v Islington Borough Council [2009] EWCA Civ 1357; McFarlane v Relate Avon Ltd [2010] EWCA Civ 880

${ }^{8}$ See for example, http://www.telegraph.co.uk/finance/newsbysector/retailandconsumer/10532782/Muslimstaff-at-Marks-and-Spencer-can-refuse-to-sell-alcohol-and-pork.html; (accessed 17 May 2017)
} 
grounds. In Ladele $v$ Islington Borough Council ${ }^{9}$ Ladele sought to be excused from carrying out civil partnerships on the basis of her religious beliefs, but permission was refused. Similarly, in McFarlane $\checkmark$ Relate Avon $\mathrm{Ltd}^{10}$ McFarlane claimed that he was discriminated against for refusing, on religious grounds, to provide psycho-sexual therapy to same sex couples. The Court of Appeal in Ladele held that the refusal to accommodate the request to be exempt from carrying out civil partnerships was justified as the employer was entitled to rely on its policy of requiring all staff to offer services to all service users regardless of sexual orientation. The decision in McFarlane was determined fairly briefly and followed Ladele: the employer's requirement that McFarlane offer therapy to all clients regardless of sexual orientation was potentially indirectly discriminatory as it put him at a disadvantage, but it was justified as a proportionate means to achieve equality on other grounds. The outcome of the two cases was upheld by the ECtHR on a similar basis: the restriction on religious freedom was justified as a proportionate means to protect the equality rights of others.

The cases illustrate the indeterminacy of indirect discrimination claims. Although both the domestic and European court decided that the employers' refusal to allow the employee's conscientious objection, it is possible, of course to imagine a different outcome of the balancing exercise, particularly given that alternative ways to accommodate the religious employees' objections were easily identifiable. For example staff could be allowed to swap clients informally, or in Ladele's case the employer could have not designated her as a civil partnership registrar, and thus precluded her from conducting the civil partnership ceremony's. ${ }^{11}$ Indeed, in Ladele the Court of Appeal was clear that it was not criticising the decision by some councils to accommodate similar requests from marriage registrars. Instead, proportionality was assessed fairly broadly, using a wide range of factors including the fact that she was employed in the public sector, and that her job was of a secular nature. ${ }^{12}$

As with indirect discrimination cases generally, the decisions in Ladele and McFarlane were based on the balancing of competing interests to achieve what the court assessed was a proportionate outcome. The proportionality approach contained within the indirect discrimination framework allows for cases to be determined with sensitivity to the individual facts of the case as well as broader contextual factors. For example, a court can give weight, as it did in Ladele and

\footnotetext{
${ }^{9}$ Ladele v Islington Borough Council [2009] EWCA Civ 1357; then heard with Eweida and Others v the United Kingdom, Application No. 48420/10, 59842/10, 51671/10 and 36516/10, 15 January 2013.

${ }^{10}$ McFarlane v Relate Avon Ltd [2010] EWCA Civ 880

${ }^{11}$ See C McCrudden, 'Marriage Registrars, Same-sex Relationships, and Religious Discrimination in the European Court of Human Rights' (2016) U of Michigan, Public Law And Legal Theory Research Paper Series Paper No. 513. SSRN, who suggests that if Ladele had not been designated as a civil partnership registrar, there would be no adverse impact on equality of opportunity for same sex couples. There may, however, be an infringing of the dignity of same sex couples if Islington were to allow staff to opt out of offering them a service.

12 Ladele $\mathrm{n} 9$ above at para 52. An additional factor in Ladele's case was that she was already in post when the civil partnerships were introduced and so she had not applied for a job which she know she could not perform; arguably she should not lose her job when the job had changed around her. However, although the job had changed during her employment, it is worth noting that changes in work tasks are often introduced by employers, particularly in response to technological or legal developments, and this does not usually give rise to rights for employees to continue to work in their previous roles. It is arguable that the new methods of working in Ladele's case were too radical in nature to be seen as part of her original contractual obligations. Yet, the fact remains that there is no inherent right for an employee to assume that her job cannot change.
} 
McFarlane, to an employer's interest in setting its own ethos, as well as recognising interests such as economic efficiency and whether the workplace is public sector or private sector.

\section{The benefits and disadvantages of the indirect discrimination model}

The cases of McFarlane and Ladele provide clear examples of how an indirect discrimination model can work to protect those with a conscientious objection to carrying out aspects of their work. They also illustrate some of the limitations of the model. In particular, its flexibility and fact-sensitive decision making gives rise to the charge that the law lacks certainty and is too indeterminate. It remains hard to predict in any particular case whether a particular conscience claim should be allowed by an employer or not.

\section{Solitary conscience claims}

An additional limitation of the indirect discrimination model has arisen in respect of individual conscience claims, where the beliefs on which the claim is based are not shared by others. Indirect discrimination claims have usually been understood as a mechanism for addressing group disadvantage, with the focus on neutral rules which put a group (women, a religious group etc) at a disadvantage compared with others not in that group. The wording of the Equality Act 2010 thus requires that the applicant must show that a neutral requirement is imposed which 'puts or would put' persons of the same religion at a particular disadvantage. The wording rarely creates difficulties in relation to sex and race discrimination, where there will always be others in the same group as the applicant. However, in the context of religious discrimination, the restriction can be significant. If an individual has a personal religious or philosophical belief which gives rise to a personal conscientious objection to carrying out an aspect of the job, it may be the case that others will also need to be disadvantaged if the applicant is to come within the indirect discrimination protection.

This issue was raised in the domestic hearings in Eweida $v$ British Airways. ${ }^{13}$ Eweida was a member of the check-in staff for British Airways, who was refused permission to wear a cross over her uniform, as this was in breach of its uniform policy. Her indirect discrimination claim was unsuccessful, because the refusal to accommodate the request of a single believer was not covered by the indirect discrimination protection, which required a group disadvantage. The definition states that a neutral requirement (here the requirement not to wear visible jewellery) be imposed which 'puts, or would put, persons of the same religion at a particular disadvantage (emphasis added)'. This suggested that more than one person must hold the belief. As Eweida was the only person identified in the proceedings who held the particular belief, there could be no indirect discrimination. The result of this ruling is that individual believers who do not share their beliefs with others are not protected by the indirect discrimination provisions in the Equality Act. ${ }^{14}$

However, it is unclear whether this limit on indirect discrimination still applies following the decision of the ECtHR in Eweida $v U K^{15}$ that Eweida's dismissal breached her right to freedom of religion or belief under Article 9 ECHR.

McCrea suggests that solitary believers are not protected under indirect discrimination provisions, even though they are protected under the human rights framework of the ECHR. ${ }^{16}$ In

\footnotetext{
${ }^{13}$ Eweida v British Airways [2010] EWCA Civ 80. See the comment on the EAT decision Vickers, [2009] Ecc LJ 197

${ }^{14}$ This approach is confirmed in Chatwal v Wandsworth Borough Council [2011] UKEAT 0487_10_0607.

${ }^{15}$ Eweida v UK [2013] ECHR 37
} 
reaching this conclusion he refers to the decision of Sedley $L$ in the Court of Appeal hearing in Eweida, in which he suggests there is "no indication that the Directive intended either that solitary disadvantage should be sufficient... or that any requirement of plural disadvantage must be dropped." Sedley $\amalg$ also refers to the fact that Disability Discrimination Act 1995 was designed to create individual claims and uses special wording to do so, implying that the wording of the indirect discrimination provisions cannot therefore have been designed to cover individual claimants.

However, although indirect discrimination has its roots in addressing group disadvantage, this should not mean that it cannot develop to protect individuals who suffer disadvantage as well. After all, the parent Directive 2000/78 is worded in the conditional tense, suggesting that it could apply to hypothetical claimants. ${ }^{17}$ Sedley LJ's reference to the Disability Discrimination Act 1995 ignores the fact that under the Equality Act 2010 all forms of indirect discrimination are protected using the same wording, without special protection for individual disability claims. Yet the Equality Act 2010 is not usually understood to have removed the protection against indirect discrimination from individual disabled people; this suggests that the definition of indirect discrimination as contained in s 19 Equality Act can be read to include protection solitary believers. Such a reading would also accord with the ECtHR decision. ${ }^{18}$

Reading the provisions of the Equality Act to comply with the ECtHR decision in Eweida involves reading provision 'puts or would put persons with whom B shares the [religion or belief] (emphasis added)' at a disadvantage to mean would put persons of the religion or belief at a disadvantage were there to be any. Although this argument was put to the Court of Appeal in Eweida, it was not accepted, on the basis that 'the argument loads far too much on to the word "would". 19

The position following later cases remains somewhat unclear. The point was discussed in Mba $v$ London Borough of Merton, ${ }^{20}$ where the Court of Appeal recognised that the protection of freedom of religion under Article 9 does not require that the claimant first establish a group disadvantage. Nonetheless, it held that this would not mean that the Equality Act 2010 should be interpreted so as to enable indirect discrimination to apply to individual claimants. ${ }^{21}$ At first, it seems that, after $\mathrm{Mba}$, group disadvantage still needs to be shown for claims of indirect discrimination under the Equality Act. However, the point was not definitively dealt with in the case, as the question of group disadvantage had been conceded on the facts; moreover, as Lord Justice Vos confirmed, this issue was not fully argued. ${ }^{22}$ The point therefore still seems to be left open, and it is arguable that despite the Court of Appeal's approach in Eweida and Mba, indirect discrimination

\footnotetext{
${ }^{16} \mathrm{R}$ McCrea, 'Singing from the Same Hymn Sheet? What the Differences between the Strasbourg and Luxembourg Courts Tell Us about Religious Freedom, Non-Discrimination, and the Secular State' (2016) 5(2) Oxford Journal of Law and Religion 183-210.

${ }^{17}$ See also N. Bamforth, M Malik and C O'Cinneide (eds) Discrimination Law, Theory and Context (London, Sweet and Maxwell, 2008), at p. 307-308

${ }^{18}$ In accordance with s 3 Human Rights Act 1998.

19 [2010] EWCA Civ 80 at para 17

${ }^{20}$ Mba v London Borough of Merton [2013] EWCA Civ 1562.

21 ibid paras. 34-35.

22 ibid para. 41.
} 
should cover individual disadvantage, particularly given that the parent Directive $2000 / 78$ is worded solely in the conditional. ${ }^{23}$

There are some clear advantages to the requirement of group disadvantage; ${ }^{24}$ in particular it would avert the danger that discrimination claims could be generated by a wide range of behaviours linked to individual beliefs. ${ }^{25}$ However, there are clear disadvantages too, not least the fact that it leaves individual believers unprotected when it comes to manifesting their beliefs at work. Allowing individual indirect discrimination cases under the Equality Act 2010 would mean that the protection would accord with Article 9, and protect the conscience claims of those who do not share their beliefs with others, and who cannot make claims directly under the Human Rights Act $1998 .{ }^{26}$ After all, allowing indirect discrimination to be used in individual conscience cases would not mean that employers would need to accommodate any and all conscience claims: any refusal which is potentially indirectly discriminatory will still need to be justified.

\section{Clarity of the provisions}

Apart from the problems of protecting individual conscience claims through indirect discrimination, there are some additional limitations to the model: it is not, on the face of it, obvious that conscience claims can be brought under this mechanism; and it could lead to a levelling down of protection for other equality grounds.

The fact that indirect discrimination provides a level of protection for those with conscientious objections to work tasks may well not be apparent to those not well versed in discrimination law. It requires claimants to know that the requirement to undertake the task is a 'provision, criterion or practice' and that their objection puts them at a disadvantage. In practice, it will usually not be claimants who recognise this, but their lawyers! Thus the fact that legal protection exists will not be evident to most of those who have a conscientious objection to performing specific work tasks.

\section{Levelling down}

The concern about the risk of 'levelling down' protection for other grounds arises because of the need to ensure consistency as between different strands of equality law in the application of indirect discrimination. ${ }^{27}$ S19 Equality Act 2010 relies heavily on the notion of proportionality, and this allows for contextual interpretation which can take into account all the circumstances of the particular case. In the context of sex or race discrimination, the test for proportionality is strict: the means chosen for achieving that legitimate aim must correspond to a real need on the part of the undertaking, must be appropriate with a view to achieving the objective in question and must be necessary to that end. ${ }^{28}$ For example, costs or inconvenience would not be acceptable as justification for indirect sex discrimination, but these factors could help justify indirect religious

\footnotetext{
${ }^{23}$ See also N Bamforth et al. n17 above at p. 307-308

${ }^{24}$ See for example, R Allen and G Moon, 'Substantive Rights And Equal Treatment In Respect Of Religion And Belief: Towards A Better Understanding Of The Rights, And Their Implications' (2000) EHRLR 580, 601.

${ }^{25}$ Eweida v British Airways [2010] EWCA Civ 80 at para 18

${ }^{26}$ Although religion and belief are protected under Article $9 \mathrm{ECHR}$, individual employees in the private sector cannot make direct claims under the Human Rights Act 1998.

27 S Benedi Lahuerta,'Taking EU Equality Law to the next level: in search of coherence' (2016) 11(3) European Labour Law Journal 348

${ }^{28}$ Bilka-Kaufhaus v Weber von Hartz [1986] ECR 1607-1631 [1986], para. 607.
} 
discrimination. If the different grounds of discrimination are meant to be interpreted similarly, a decision that economic cost can justify religious discrimination could result in a finding that the same were true of sex or race discrimination.

One solution to this problem would be to allow a hierarchy to develop whereby different grounds of equality are explicitly given different levels of protection. However, such an approach would be contentious. ${ }^{29}$ An alternative is to introduce separate protection for religion or belief, to avoid any 'cross contamination' of standards of protection. If a separate legal mechanism were to be used, designed to address religious claims, it may also be more easily understood by users. The obvious contender for such a new legal mechanism is the duty of reasonable accommodation, and to this I now turn.

\section{The reasonable accommodation model}

The reasonable accommodation model creates an obligation on employers to accommodate requests from employees for changes to working conditions, as long as it is reasonable to do so. The mechanism puts the onus on the employee to seek the accommodation, which the employer would then be under an obligation to agree, unless it is reasonable not to do so. Accommodations based on conscience would include requests to be exempt from performing particular work tasks. For example, Ms Ladele's claim would be recast as a request that her refusal to perform civil partnerships be granted (accommodated) by the employer.

The concept of accommodation is already part of domestic disability discrimination law, with its duty on employers to make reasonable adjustments to the workplace. This recognises the fact that changes to the workplace to allow full participation by disabled people will need to be very individualised. The focus therefore needs to be on adapting workplaces to the individual needs of disabled people. As with the variety of experiences of disability, religious practices and conscience claims can vary widely, and so a personalised duty of reasonable accommodation for religious needs may well be thought an appropriate way forward to improve the protection of religious interests at work.

The concept certainly has received significant academic support, on the basis that it can improve protection for religion or belief in employment, ${ }^{30}$ and help reduce the inconsistency and incoherence currently identified within EU equality law. ${ }^{31}$ Moreover, to the extent that the concern regarding individual claims remains valid, it would be overcome by the creation of a duty of reasonable accommodation.

\footnotetext{
${ }^{29}$ The creation of a 'hierarchy' of equality rights, is something which was warned against in the Commission's 'Explanatory Memorandum' to the Directives: Proposal for a Council Directive: Establishing a General Framework for Equal Treatment in Employment and Occupation COM (1999) 565 final, 6

${ }^{30}$ M Gibson, 'The God "dilution"? Religion, discrimination and the case for reasonable accommodation' (2013) 72 (3) Cambridge Law Journal 578; See also Clearing the Ground: Preliminary Report into the Freedom of Christians in the UK. (2012, London: Christians in Parliament); K Alidadi, 'Reasonable accommodations for religion and belief: Adding value to Art.9 ECHR and the European Union's anti-discrimination approach to employment?' (2012) 37 (6) European Law Review 693; E Bribosia, J Ringelheim, \& I Rorive, 'Reasonable Accommodation for Religious Minorities-A Promising Concept for European Antidiscrimination Law?' (2010) 7 Maastricht Journal of European and Comparative Law 137

${ }^{31}$ S Benedi Lahuerta n 27 above.
} 
A duty of reasonable accommodation was suggested for the UK by the Independent Review of the Enforcement of UK Anti-Discrimination Legislation. ${ }^{32}$ It has more recently been proposed as a way to manage religious interests in the work place by the think tank Res Publica. ${ }^{33}$ Lady Hale has also give it her support, although within the framework of indirect discrimination law, stating that she is 'more than ready to accept that the scope for reasonable accommodation is part of the proportionality assessment, at least in some cases. ${ }^{\prime 34}$ In addition, at European level, the EU funded Religare project ${ }^{35}$ recommended in its final report that a legally enshrined right to reasonable accommodation of religion or belief at work would fill the gaps in existing legal protection and better meet the needs of religious employees. To this can be added an EU Parliamentary Assembly resolution, ${ }^{36}$ inviting States to seek reasonable accommodations in order to guarantee effective equality in terms of freedom of religion; and the support of the UN Special Rapporteur on freedom of religion or belief. ${ }^{37}$

In order to assess whether the introduction of a duty of reasonable accommodation would provide a better mechanism for protecting conscientious objection within the employment context, it is worth considering its operation in two other jurisdictions.

\section{The Duty of Reasonable Accommodation in the United States of America}

In the USA, anti-discrimination provisions are contained in Title VII of the Civil Rights Act $1964 .{ }^{38}$ In addition, government workers are protected against religious discrimination under the Constitution, and many individual states have their own human rights laws which cover discrimination. Title VII includes a duty of reasonable accommodation and is the focus of what follows.

The Civil Rights Act did not originally contain a duty of reasonable accommodation, however, soon after its enactment, it was felt that amendment was required to make clearer that religious freedom requires the protection of religious practice or observance, as well as protection of belief itself, and so it was amended to include a duty on the employer to accommodate the religious practices of employees, as long as to do so did not cause undue hardship to the employer. ${ }^{39}$

The provisions cover all forms of accommodation, and would include the types of request that arise from conscientious objection. The duty requires that religion be accommodated unless

\footnotetext{
${ }^{32}$ B Hepple, M Coussey and T Choudhury, Equality: A New Framework-The Report of the Independent Review of the Enforcement of UK Anti-Discrimination Legislation (Oxford, Hart Publishing, 2000).

33 James Orr, 'Beyond Belief Defending religious liberty through the British Bill of Rights' (2016) Res Publica

${ }^{34}$ Per Lady Hale, Bull \& Anor v Hall \& Anor [2013] UKSC 73 at para 47; Lady Hale 'Religion and Sexual

Orientation: The clash of equality rights' 7 March 2014. Speech at the Comparative and Administrative Law

Conference, Yale Law School www.supremecourt.uk/docs/speech-140307.pdf.

${ }^{35} \mathrm{http}: / / \mathrm{www} \cdot$ religareproject.eu/

${ }^{36}$ assembly.coe.int/nw/xml/XRef/Xref-XML2HTML-en.asp?fileid=22199\&lang=en

372014 interim report of the UN Special Rapporteur on Religion and Belief, which focussed on tackling religious intolerance and discrimination in the workplace available at 2014 interim report of the UN Special Rapporteur on Religion and Belief, which focussed on tackling religious intolerance and discrimination in the workplace available at www.ohchr.org/Documents/Issues/Religion/A.69.261.pdf.

${ }^{38} 42$ USC§ 2000e-2.

${ }^{39}$ The amendment was made to the definition of religion: The term 'religion' includes all aspects of religious observance and practice, as well as belief, unless an employer demonstrates that he is unable to reasonably accommodate to an employee's or prospective employee's religious observance or practice without undue hardship on the conduct of the employer's business; 42 USCA $\S 2000 \mathrm{e}$. Failure to offer reasonable accommodation can make the employer liable for punitive damages.
} 
there is undue hardship, interpreted to mean that, if accommodation is to be required, there must be no more than de minimis cost, either in terms of financial cost or in terms of disruption, or administrative inconvenience. ${ }^{40}$ As a result of the low level of hardship required, employers are left with a rather slender duty to accommodate.

Although the level of hardship that needs to be shown is very low, there are some limits on what can be undue hardship, such as to limit the duty of accommodation. Any hardship must operate on the conduct of the employer's business. ${ }^{41}$ It must create some form of economic hardship, and cannot be merely hardship of a spiritual nature. For example, in Townley Engineering, ${ }^{42}$ where the employer sought to run the business as a Christian, faith-operated business, weekly mandatory devotional services were held during working time, and the employer sent out gospel tracts with outgoing mail and printed bible verses on invoices. The employers argued that accommodating an atheist employee by excusing him from attendance at the weekly service would cause 'spiritual' hardship to the company as it would 'chill' their religious purposes. The Court accepted that spiritual hardship could exist, but held that the restriction in the legislation to hardship in the conduct of the business ruled out the use of non-economic harm to justify a refusal to accommodate religion.

Excluding spiritual hardship may make it harder to override the duty to accommodate, but the low level of economic hardship required still means it is fairly easy to override the duty in practice. The main parameters of the duty of accommodation were set out in two cases before the Supreme Court, both involving members of the Worldwide Church of God. In Trans World Airlines, Inc $v$ Hardison ${ }^{43}$ a clerk in the stores department of TWA asked to change his hours to avoid working from sunset on Friday until sunset on Saturday. The shift system at TWA was operated on a seniority basis, agreed through a collective bargaining system. At first, Hardison's request was accommodated, as he had sufficient seniority to enable him to be given his requested shifts in accordance with the collectively agreed system. However, after being moved to a new part of the business he lost seniority, and could no longer arrange shifts to suit his religious beliefs. The union was unwilling to agree a waiver of the seniority system to enable his beliefs to be accommodated, and TWA would not allow him to work a four-day week as that would mean incurring the additional expense of employing an extra worker for Saturdays. When he was dismissed, the court had to determine whether a reasonable accommodation had been available for Hardison. The Supreme Court ruled that the options available to the employer (overriding the seniority system that had been agreed with the union, or allowing Hardison to work a four-day week at extra cost to the employer) would have imposed undue hardship on the employer. The Court took the view that to override a seniority system would mean denying one member of staff's preference in favour of another's preference, and would not be reasonable. Overall, they ruled, the employer does not need to take on more than de minimis costs in order to offer reasonable accommodation.

The second case, Ansonia Board of Education v Philbrook, ${ }^{44}$ involved a request to use 'personal business' leave to supplement leave for religious observance, so as to enable the applicant

\footnotetext{
${ }^{40}$ Ansonia Board of Education v Philbrook 479 US 60 (1986).

${ }^{41} 42$ USCA $\S 2000$ e j.

42 Townley Engineering 859 F 2d 610 (9th Cir 1988).

${ }^{43}$ Trans World Airlines, Inc v Hardison 432 US 63 (1977).

${ }^{44}$ Ansonia n 40 above.
} 
to take sufficient paid days off for religious observance. The employer would not allow the paid 'personal leave' days to be taken for this purpose. The employer was only prepared to accommodate the request for extra leave by allowing Philbrook to take unpaid leave. The question which arose was whether the employee has to accept a reasonable offer of accommodation once it is offered (here the unpaid leave) or whether he can claim that a failure to offer his preferred accommodation (here the paid 'personal business' leave) is unreasonable. The Supreme Court held that once the employer has shown that a reasonable accommodation has been offered, the employer's duty ends. The fact that an employee can identify an alternative accommodation which he or she would prefer does not change matters: the employer is under no obligation to offer the employee the least disadvantageous accommodation available. ${ }^{45}$ There is a requirement on the employee to be flexible in accepting an accommodation if it is reasonable, even if he can identify less disadvantageous accommodations.

The combined effect of Hardison and Philbrook is that, although a duty to accommodate exists, it is so easily overridden that employees' religious interests are given very little practical protection. Once a countervailing interest is identified, the duty on the employer to accommodate religion tends to give way. In this respect, the level of accommodation required for religious claims can be contrasted with that required in disability cases, where undue hardship is defined to mean an action requiring significant difficulty or expense. ${ }^{46}$

In religion and belief cases, it would seem, then, that what is given with one hand via the duty of accommodation is taken away with the other via the low level of hardship needed to defeat the duty. ${ }^{47}$ In effect, changing the mechanism for protecting conscience claims from a nondiscrimination approach to a reasonable accommodation approach is not a panacea; the duty of reasonable accommodation is only as strong as the standards of reasonableness applied.

However, even though the standard of hardship is set low in the USA, with only de minimis hardship required, employers are required to make some attempt at accommodation. One matter which can give rise to hardship to the employer is a negative reaction to any accommodation by other staff. The cases are not always consistent on this issue. On the one hand, a refusal by other staff to accept a religious practice can give rise to undue hardship for the employer, and can give grounds to refuse to accommodate. Thus, in Wilson $v$ US West Communications ${ }^{48}$ a Catholic employee, who wore a badge with a picture of an aborted foetus on it as part of a vow to be a living witness' against abortion, was dismissed because her colleagues found the badge offensive. The court held that the duty to accommodate did not require an employer to allow an employee to impose her views on others. On the other hand, any hardship to the employer must be real, and cannot be purely hypothetical. Thus, in Burns $v$ Southern Pacific Transportation $\mathrm{Co}^{49}$ the employer argued that to accommodate a Seventh Day Adventist's conscientious objection to paying union

\footnotetext{
${ }^{45}$ In reaching this conclusion, the Supreme Court disregarded guidelines produced by the US Equal Employment Opportunity Commission (EEOC) that suggested that where there is an alternative accommodation which does not cause hardship, the employer should offer the one which least disadvantages the religious employee. See also EEOC v llona of Hungary 108 F 3d 1169 (7th Cir 1997).

${ }^{46}$ Amercians with Disabilities Act (1990) 42 USC Sec. 12111 (10).

${ }^{47}$ See, further, J D Prenkert and J M Magid, 'A Hobson's Choice Model for Religious Accommodation' (2006) 43:3 American Business LJ 467.

48 Wilson v US West Communications 58 F 3d 1337 (1995).

${ }^{49}$ Burns v Southern Pacific Transportation Co 589 F 2d 403 (9th Cir 1978).
} 
dues would cause dissention among workers, leading to inefficiency. This was rejected by the court, which stressed that undue hardship requires more than just proof that some employees would grumble. The employer would need to show that other employees were imposed upon, or that the work routine would be disrupted. ${ }^{50}$

The duty of reasonable accommodation has been used in the US in the context of conscientious objection to work tasks, although the hardship caused to employers in having to make special arrangements in the assignment of work will usually mean that requests do not have to be accommodated. Moreover, the matching duty on religious employees to be flexible and to accept the accommodations offered by the employer ${ }^{51}$ also means that they will find it difficult to claim that a failure to allocate tasks according to religious preference is unlawfully discriminatory. Accommodations such as allowing voluntary swaps of tasks, or offering to redeploy are reasonable, ${ }^{52}$ although this will only be feasible where the employer is large enough and skills are transferable. In the case of medical staff who wish to avoid providing medical care such as abortion, they would also be expected to refer patients to staff who will provide the service. Where the reallocation of work is not practical, dismissal can be lawful. Thus, in a case reminiscent of McFarlane, where a counsellor refused, for religious reasons, to counsel clients who were homosexual or who were involved in extra-marital relationships, dismissal was not discriminatory: it would not be possible to determine in advance whether such an issue may arise in a counselling relationship, and to allow staff to opt out of some tasks would lead to an uneven distribution of work among colleagues. ${ }^{53}$

Some employees in the US have claimed that they have religious objections to participating in training or complying with workplace diversity policies, particularly where they believe it requires them to condone homosexuality. Employers have not generally been required to accommodate such objections. The need to promote diversity and tolerance within the workplace has been seen as legitimate, and the hardship caused to an employer if he is prevented from promoting such a culture at work is seen to override any duty to accommodate religion. Thus in Peterson v Hewlett Packard ${ }^{54}$ Peterson refusal to desist from displaying bible verses denouncing homosexuality in response to posters celebrating the diversity of the Hewlett Packard workforce led to his dismissal. This was held not to be discriminatory: to require the employer to stop the diversity programme would have amounted to undue hardship.

Interestingly, the courts have allowed some accommodation of religious views which are critical of homosexuality, where to do so does not lead to any active discrimination against other workers. For example, Buonanno v AT\&T Broadband $L L C^{55}$ involved an employee who was required to sign a diversity statement which stated that he 'valued' the differences among people. He claimed that this required him to make a statement which was supportive of homosexuality, even though this was incompatible with his religious view that homosexuality was sinful. He was prepared to sign an alternative statement agreeing to value the fact that there are differences between people (as opposed to valuing the differences themselves). Given that the employee in question had no

\footnotetext{
${ }^{50}$ See also Tooley v Martin-Marietta Corp 648 F 2d 1239 (1981), and Townley Engineering above n 42.

${ }^{51}$ Ansonia $\mathrm{n} 40$ above

52 Shelton v University of Medicine and Dentistry of New Jersey 223 F 3d 220 (2000).

${ }^{53}$ Bruff v North Mississippi Health Services 244 F 3d 495 (2001).

54 Peterson v Hewlett Packard 358 F 3d 599 (9th Cir 2004).

${ }^{55}$ Buonanno v AT\&T Broadband LLC 313 F Supp 2d 1069 (2004).
} 
intention of discriminating against or being disrespectful towards homosexual staff, and that a form of words which was compatible with the employer's diversity policy could have been found, the court determined that the employee's religious objections to the standard diversity statement should have been accommodated. The employer's refusal to investigate the possibility of an alternative wording amounted to a failure to accommodate: investigating a minor amendment to the wording of the statement would not cause undue hardship to the employer. It was significant to the decision that Buonanno was not asking to be exempt from the duty to respect others in the workplace. Indeed, he was prepared to sign a statement which involved a commitment to respect others. However, he was not prepared to sign a statement with which he disagreed, on religious grounds. In terms of balancing interests, Buonanno's freedom of conscience could be accommodated as long as he was prepared to respect the diversity policy of the company in practice.

The cases illustrate that a range of fairly low level accommodations can be found to be reasonable by the courts, but the duty stops well short of creating anything like a right to conscientious objection to work tasks. However, the duty does achieve some measure of protection for religious interests at work, as it requires that employers make an attempt to accommodate. Although only de minimis hardship is required, it must be real and not merely hypothetical. In effect, the onus is put on the employer to show that they have thought about trying to accommodate and have actual reasons why to do so would be difficult. Moreover, the duty provides a mechanism whereby employees will feel free to request an accommodation, and means that conscience claims must be considered by the employer, who may only reject them where they clash with other interests.

\section{The Duty of Reasonable Accommodation in Canada}

The legal protection against discrimination in Canada is provided within a federal legal system, with equality provisions contained in the legislation of the relevant province. All provinces, municipal and federal governments are also subject to the Canadian Charter of Rights and Freedoms, and the Canadian Human Rights Act, ${ }^{56}$ which contain general non-discrimination guarantees. Although this creates a number of different religious equality provisions, most follow the same basic model, and although the wording of the various provisions differs, this seems to make little difference to the outcome of cases. ${ }^{57}$

Discrimination on grounds of religion is unlawful. An exception exists where there is a bona fide occupational requirement to be of the particular religion. In some provinces there is an explicit requirement on employers to accommodate the religious employee up to the point of undue hardship. ${ }^{58}$ Other provinces do not have an explicit requirement, but the overall protection is very similar: the Supreme Court case law makes clear that there is an overarching duty to accommodate up to the point of undue hardship, and the duty can be understood to form part of the nondiscrimination duty. In order to show that an employer's requirements are necessary, it must be

\footnotetext{
${ }^{56}$ RSC 1985, c H-6. The Canadian Human Rights Act has less impact as it only applies to the few federally regulated industries such as banking, shipping, federal public service, post office, etc.

${ }^{57}$ More detail, particularly on the separate provincial laws, can be found in W Tarnopolsky and W Pentney, Discrimination and the Law (Toronto, Carswell, 2005).

${ }^{58}$ See Manitoba Human Rights Code section 9, which contains a duty of reasonable accommodation.
} 
shown that the employer cannot accommodate the employee's request for variation in the work rules, without undue hardship. ${ }^{59}$

Early Canadian cases took a similar approach to the USA, with the view that requiring that an employer bear anything more than a de minimis cost was 'undue hardship' (and therefore not required of an employer). ${ }^{60}$ However, the law has developed so that employers are required to go further to accommodate religious practice, ${ }^{61}$ while still acknowledging that it can be acceptable for the employee to bear some of the costs of religious practice. Factors that can be taken into account in assessing whether there is undue hardship include financial cost, disruption of a collective agreement, problems of morale of other employees, interchangeability of workforce and facilities, size of employer and the ease with which the workforce can be adapted. ${ }^{62}$ Although the list of factors which can justify failure to accommodate is extensive, the Canadian duty to accommodate is stronger than that in the USA. The decision in Meiorin ${ }^{63}$ confirmed that accommodation will be required unless it is impossible to do so without undue hardship. Although case law shows that a higher level of accommodation is required in the Canadian courts, it should be noted that the Meiorin test is not that if an accommodation is possible it must be offered: the test remains subject to undue hardship. Only if it is possible to accommodate without undue hardship will accommodation be required. If it is possible to accommodate, but to do so imposes undue hardship, then the accommodation will not be required.

Although the duty of accommodation does not require all religious requests to be granted, failing to consider options for accommodation may result in a discrimination finding. Once a potential accommodation has been identified by an employee, the employer effectively becomes under an obligation to consider an accommodation. In Qureshi v G4S Security Services ${ }^{64}$ the employer rejected the applicant once it learnt of his need for time off to pray for an hour every Friday. The Human Rights Tribunal of Ontario held this was discriminatory. It confirmed that the duty to accommodate has both a substantive and procedural component, and that there was a duty on the employer to take adequate steps to assess and explore accommodation options once it was aware of the potential need for accommodation: there was no need to wait for a request from the employee. Failure to meet the procedural requirement to consider accommodation could be sufficient to establish discrimination, although on the facts, the tribunal also found that there was no undue hardship: the claims about hardship were vague and speculative, and no clear evidence had been provided.

A number of specific exceptions allow staff to refuse to undertake certain work tasks. For example, professional bodies, such as physicians, make explicit allowance for their members to

\footnotetext{
${ }^{59}$ British Columbia (Public Service Employee Relations Comm) v BCGEU [1999] 3 SCR 3 ('Meiorin') and confirmed in British Columbia (Superintendent of Motor Vehicles) v British Columbia (Council of Human Rights) [1999] 3 SCR 868 ('Gismer'). In some provinces, the exception only applies to religious organisations operating in a not-for-profit environment.

${ }^{60}$ Froese v Pine Creek School Division No 30, M Rothstein QC, 28 December 1978 (Man Bd Adjud) (unreported).

${ }^{61}$ Central Okanagan School District No 23 v Renaud [1992] 2 SCR 970, a case involving dismissal for refusing to work days designated as holy by the employee's religion.

${ }^{62}$ Central Alberta Dairy Pool v Alberta (Human Rights Commission) [1990] 2 SCR 489.

${ }^{63}$ British Columbia (Public Service Employee Relations Comm) v BCGEU [1999] 3 SCR 3 ('Meiorin')

${ }^{64}$ Qureshi v G4S Security Services 2009 HRTO 409 (CanLII)
} 
conscientiously object to performing abortions, ${ }^{65}$ and section 3 of the Civil Marriage Act recognises that officials of religious groups are free to refuse to perform marriages that are not in accordance with their religious beliefs. However, as in the UK, religious individuals employed as civil marriage commissioners are not given exemption from performing same-sex marriage. ${ }^{66}$

In more general terms, claims for conscientious objection to performing particular work tasks will be dealt with as a matter of accommodation. In Moore $v$ British Columbia (Ministry of Social Services), ${ }^{67}$ a financial aid worker was dismissed for refusing to grant a client financial aid for an abortion, because of religious objections to abortion. The Human Rights Council decided that as the employer had taken no steps to accommodate her religious views, Moore had suffered religious discrimination. For example, requests of the type refused by Moore were relatively infrequent, and other workers could have been asked to deal with them. What is interesting about the case is that, although it was suggested that Moore should have removed herself from the client's case (rather than taking it on and then refusing assistance), it did not place much responsibility on the employee to avoid the problem of clashes between religious scruple and compliance with the employer's reasonable job requirements. ${ }^{68}$ The issue was not discussed because it was clear that no attempt to accommodate had been made. However, it may well be that in some cases the onus will pass to the employee not to undertake work which he or she is unable fully to perform on religious grounds.

Canadian courts put an onus on both parties to compromise when it comes to accommodating religion at work. Employers are required to do more than merely show that there is some impact upon their business: they can be required to tolerate some level of inconvenience or expense. To this extent, the approach in Canada can be contrasted with that in the USA. The Canadian courts have recognised equally that it is acceptable to allow some cost on the employee's part, thus achieving a reasonable balance between the interests of the religiously observant employee and the needs of the employer.

However, as with the position in the USA, any additional protection for religious interests provided by a duty to accommodate is only strong if that duty cannot be easily overridden. The 'undue hardship' standard can be easily met in the US; the Canadian duty is stronger, as 'undue hardship' is harder to show. What this shows is that the level of protection provided does not necessarily depend on the legal framework: whether there is a duty to accommodate or a duty not to discriminate indirectly, the strength of the protection will be determined by the scope of the proportionality or 'hardship' review.

Nonetheless, although a duty of accommodation does not necessarily lead to a change in the level of protection provided, there may be other reasons for introducing an approach to the protection of conscience claims through a duty of reasonable accommodation, as discussed below.

\footnotetext{
${ }^{65}$ See for example, College of Physicians and Surgeons of Ontario, 'Professional Obligations and Human Rights' www.cpso.on.ca/policies-publications/policy/professional-obligations-and-human-rights. The obligation to refer patients to other staff who will provide the service has been challenged on religious freedom grounds: //www.cbc.ca/news/canada/ottawa/doctors-make-charter-challenge-on-right-to-refuse-care-on-religiousgrounds-1.3006462

66 In the matter of Marriage Commissions [2011] SKCA 3

67 Moore v British Columbia (Ministry of Social Services) (1992) 17 CHRR D/426.

${ }^{68}$ See W Tarnopolsky and W Pentney, Discrimination and the Law (Toronto, Carswell, 2005) para 6.2(d).
} 


\section{Is a reasonable accommodation model a better way to deal with conscientious objection?}

It is sometimes assumed that a change to a reasonable accommodation model would lead to a different outcome in cases such as Ladele. ${ }^{69}$ Just as some doctors are able to refuse to perform abortions, with patients referred elsewhere, so, Ms Ladele's request not to perform civil partnerships could be readily accommodated. She could have not been designated a civil partnership registrar, or she could have arranged for other staff to perform civil partnerships in her place. Such accommodation was indeed offered by other councils, so it was entirely practicable. This raises the question of whether such an approach would be a preferable means to deal with conscientious objections at work.

The first question that arises when addressing the question of whether or not it would be beneficial to introduce a duty of reasonable accommodation in the UK is whether such a duty would merely replicate the protection that already exists. After all, the indirect discrimination provisions of the Equality Act 2010 already amount, in effect, to a duty of reasonable accommodation in practice. As seen in Ladele in the domestic hearing under the Equality Act, the employer's requirement that all staff perform civil partnerships put members of staff with a conscientious objection to doing so the at a particular disadvantage, and so the requirement had to be justified as a proportionate means of achieving a legitimate aim. The case can thus be reframed as a reasonable accommodation claim, but the assessment of whether a failure to accommodate was reasonable would effectively be determined by considering the same matters as when determining whether it was proportionate.

The fact that a duty of reasonable accommodation can be read into our understanding of indirect discrimination was effectively accepted by Lady Hale in Hall $v$ Bull where it was suggested that the extent to which it is reasonable to expect the employer to accommodate the employee should be taken into account in the overall proportionality assessment. ${ }^{70}$ This inherent link between reasonable accommodation and indirect discrimination is also implicitly accepted in Achbita $v$ G4S, ${ }^{71}$ where the CJEU suggested that it could take into account whether the employer had tried to find alternative work for the employee when assessing proportionality. The requirement to engage in some dialogue to see if there are other roles that the employee could fulfil creates a level of obligation on employers to try to accommodate religious employees in other roles, whilst stopping short of creating a separate duty to accommodate.

It seems then that the creation of a separate and explicit duty of reasonable accommodation would not materially change the level of protection available for religion or belief in the workplace. Framing such a request as one for the accommodation which cannot be unreasonably refused does not add additional protection to that available using the indirect discrimination provisions. ${ }^{72}$ Taking the case of Ladele as an example again, the question whether Ms Ladele could refuse to carry out civil partnerships will not turn on whether the protection is framed as indirect discrimination or reasonable accommodation, but instead will be determined by whether a court decides that a

\footnotetext{
69 M Gibson, 'The God “dilution”?' n 30 above; C McCrudden, Marriage Registrars n 11 above.

${ }^{70}$ Bull \& Anor v Hall \& Anor [2013] UKSC 73 at para 47

${ }^{71}$ Case C-157/15 Achbita v G4S, 14 March 2017

${ }^{72}$ Assuming, as argued above, that indirect discrimination can be used by individual claimants.
} 
refusing to allow her conscientious objection is justified, or (what amounts to the same question, albeit framed differently) whether it is unreasonable. ${ }^{73}$

It can clearly be seen from the consideration of the North American experience that there is nothing inherent in the use of the term 'reasonable' in place of the term 'proportionate' or 'justified' which guarantees any specific level of protection. The two jurisdictions use the same framework, the duty of reasonable accommodation, but the standards of protection vary, as the different courts assess 'undue hardship' differently. It may be the case that Canadian courts have provided a greater degree of accommodation for religious conscience, but this cannot be due to its use of a particular legal mechanism, or else the US would have the same levels of protection. If the Canadian courts were to use an indirect discrimination approach it could just impose a stricter notion of justification to achieve the same levels of protection. It is thus not the legal mechanism which affects the level of protection for conscience claims, but more the question of judgment applied by the courts.

If the legal framework does not seem to effect the level of protection afforded, why then might one argue for the creation of a duty to accommodate? Reasons relate to procedural matters such as the burden of proof; clarity and ease of use; and the symbolic and practical implications of separating the legal treatment of religious equality from other equality grounds.

First, in relation to discrimination, although the burden of proof is favourable to individuals claiming that they have been discriminated against, the onus remains on the claimant to show that a requirement has been imposed that puts him or her at a disadvantage. The burden then shifts to the employer to justify the requirement. In contrast, with a duty of reasonable accommodation, the employee merely has to ask for an accommodation and the employer will then need to show that any accommodation would be unreasonable. There is no need to identify others who are also disadvantaged, in fact no need to find comparators at all. The creation of an individualised duty of reasonable accommodation suggests that each case can be assessed on its own merits, with a personalised assessment, ${ }^{74}$ and without the need for generalised group disadvantage. Thus, using a duty of reasonable accommodation approach is not only easier from the point of view of initiating a claim, but it also avoids the difficulties discussed above surrounding the question of whether there needs to be a group disadvantage. ${ }^{75} \mathrm{In}$ addition, the duty of accommodation also makes clear that it can be used for one off claims rather than ongoing changes to work.

Second, the duty of accommodation may be more intuitive and straightforward for employees to use. ${ }^{76}$ It is clear on its face that it creates rights for the employee with regard to religion and belief at work. This overcomes the problem identified above, that it may not be apparent to those not well versed in discrimination law that indirect discrimination can offer them any legal protection. The creation of a discrete 'right to reasonable accommodation' would make the

\footnotetext{
${ }^{73}$ A Stein, 'Reasonable Accommodation for Religion and Belief: Can it be Accommodated in EU Law without an Express Duty?' in M-C Foblets, K Alidadi, JS Neilsen, and Z Yanasmayan, (eds) Belief, Law and Politics: What Future a Secular Europe? (Farnham, Ashgate 2014)

${ }^{74}$ See K Alidadi, 'Reasonable accommodations for religion and belief' n 30 above.

75 If a group is required before a claim can be made, this also raises the question of how the members of that group should be identified. See F. Ast, 'Reflections on the Recognition of a Right to Reasonable Accommodation in EU Law' in M-C. Foblets, et al. n 73 above.

${ }^{76} \mathrm{~K}$. Alidadi, 'Reasonable accommodations for religion and belief' $\mathrm{n} 30$ above
} 
existence of the right much more visible and therefore more accessible to employees and employers.

The creation of a separate duty of reasonable accommodation may also be more accessible to workers because they find it less confrontational to frame religion or belief requests in terms of a request for accommodation rather than as a claim of indirect discrimination. ${ }^{77}$ Instead of having to allege that their employer has discriminated against them, religious employees may feel more comfortable merely requesting an accommodation. Such an approach could lead to more open dialogue about religion or belief in the workplace, as claims would feel less like allegations of wrongdoing made about the employer, and therefore more likely to lead to constructive dialogue and compromise. ${ }^{78}$

Yet, although a move to a duty of reasonable accommodation may look as if it will result in greater clarity and ease of use for employees, such an outcome is not inevitable. Although a duty may seem to provide clarity, the creation of a special duty of reasonable accommodation for religion and belief at work could result in some misconceptions. Certainly while on the face of it, the duty of accommodation seems clearer, the level of hardship that would be needed before an accommodation is said not to be reasonable has not been determined, and litigation is likely to be required before any real clarity is achieved. ${ }^{79}$ Even then, if the duty of accommodation results in more individualised, case by case assessment of requests, then clarity for employers and employees may be elusive in practice. As Pitt points out, ${ }^{80}$ employment tribunals may struggle for consistency on when an accommodation is reasonable. Decisions are likely to vary, with no appeal allowed on the factual conclusions reached by tribunals as long as they have properly directed themselves. The lack of clarity in the level of accommodation required (added to inherent lack of clarity regarding the meaning of the key terms of 'religion' and 'belief') means that the true scope of any proposed duty of reasonable accommodation of religion and belief is very hard to anticipate.

Although what is required under a duty of reasonable accommodation should eventually become clear, it is not evident that any such clarity would be unqualifiedly positive. Most of those calling for the introduction of a duty of accommodation have assumed that it would lead to increased protection for employees with a religion or belief. ${ }^{81}$ However, this is not necessarily the case, as the level of protection would depend on the level of hardship required before an accommodation would be said to be unreasonable and so not required. Moreover, even if greater protection were to result, whilst popular with some, ${ }^{82}$ many others would not support an increase in the protection of religion and belief at work. ${ }^{83}$ In particular, there is concern that by framing the

\footnotetext{
${ }^{77}$ K. Alidadi, ibid.; M. Gibson, M. 'The God “dilution"?' n 30 above.

${ }^{78}$ See P. Edge and L. Vickers, 'Review of equality and human rights law relating to religion or belief' Research Report 97 (EHRC, London, 2015)

79 ibid.

${ }^{80}$ G. Pitt, 'Taking religion seriously'(2013) 42 (4) Industrial Law Journal 398

${ }^{81} \mathrm{~K}$. Alidadi, $\mathrm{n} 30$ above.

${ }^{82}$ See for example, Clearing the Ground: Preliminary Report into the Freedom of Christians in the UK. (2012, London: Christians in Parliament); see also some of the responses cited in M Mitchell and K Beninger (with $\mathrm{E}$ Howard and A Donald) (2015) Religion or belief in the workplace and service delivery. (Manchester: Equality and Human Rights Commission).

${ }^{83}$ See responses in some of the workshops reported in P. Edge and L. Vickers, 'Review of equality and human rights law relating to religion or belief' $\mathrm{n} 78$ above. See also D. Pollock, Personal Memorandum of Evidence to the Commission on Religion and Belief in British Public Life, available at www.thinkingabout
} 
protection for religious practice at work as a duty to accommodate, an onus is put on the employer to acquiesce to requests. As Pollock suggests, the emphasis is on reaching a compromise, even of 'splitting the difference', rather than on looking objectively at whether a practice puts a particular religious group at a disadvantage, and whether it can be justified as a proportionate means of achieving a legitimate aim. Moreover, any pressure to compromise brings with it the concomitant concern that religions with greater demands will be granted greater accommodation.

The fact that it is not clear from the nature of the mechanism itself whether a duty of reasonable accommodation could lead to greater protection than the indirect discrimination mechanism reveals the lack of any clear theoretical underpinning for the duty of accommodation. Although the aims of non-discrimination law is an area of extensive academic debate, ${ }^{84}$ the parameters of our equality norms are long established; courts are fairly clear about the scope of the law, and how to balance the respective rights of employees and employers. In contrast, a theoretical underpinning for the duty of accommodation of religion at work is less well developed. On the one hand, it can be understood to form part of the general non-discrimination law, in which case one might expect that the standard of reasonableness will remain very close to that of justification and proportionality under indirect discrimination. On the other hand, its theoretical basis may come from the ECHR, with its focus on religion as a key aspect of pluralism, and respect for cultural diversity and traditions. ${ }^{85}$ Indeed, development of a duty of reasonable accommodation would be consistent with the decision of the ECtHR in Thlimmenos $v$ Greece. ${ }^{86}$ Here it was accepted that failure to accommodate religious difference resulted in unequal treatment, because it amounted to a refusal to treat different people differently. However, the ECtHR has only recently accepted that the right to freedom of religion of belief may survive entry to the workplace. Its jurisprudence on the right to conscientious objection at work is not well developed, having largely been based on conscientious objection in the context of military service. There may therefore be little by way of guidance available to courts as they find their way to establishing what is reasonable in the work context.

The arguments in favour of creating a new duty of accommodation, while backed by some in the $\mathrm{EU},{ }^{87}$ thus remain contentious. Any perceived advantages for religious individuals, such as clarity and ease of use, are, on closer examination, fairly fragile; and furthermore, any move to increase the protection for religion at work would certainly not be supported by all.

humanism.org/wp-content/uploads/2014/12/Commn-on-R+B-in-Public-Life-David-Pollock-evidence.pdf; and the Report of the Commission on Religion and Belief in British Public Life, Living with Difference: community, diversity and the common good (The Woolf Institute, Cambridge, 2015).

${ }^{84}$ See for example, D. Hellman and S. Moreau (eds) Philosophical Foundations of Discrimination Law (Oxford, OUP, 2013), T. Khaitan, A Theory of Discrimination Law (Oxford, OUP, 2015), I Solanke, Discrimination as Stigma: A Theory of Discrimination Law (2016, Hart Publishing, Oxford), S Fredman, Discrimination Law (Oxford, OUP, 2002), Hepple, 'The Aims of Equality Law' in O'Cinneide and Holder (eds) Current Legal Problems (Oxford, OUP,2008). See also N Fraser, 'Rethinking Recognition' (2000) 3 New Left Review 107, and C Taylor, Multiculturalism and the Politics of Recognition (Princeton, Princeton University Press, 1992).

${ }^{85}$ Moscow Branch of the Salvation Army v. Russia (2007) 44 EHRR 46, para 61. See C McCrudden, Marriage Registrars $\mathrm{n} 11$ above.

${ }^{86}$ Thlimmenos $v$ Greece (2001) 31 EHRR 15. Note, however, that the case law of Art 9 ECHR does not impose a duty to accommodate religion at work. See Ahmad v UK (1981) 4 EHRR 126 and Stedman v UK (1997) 23 EHRR CD168, both confirmed in Kosteski v 'The Former Yugoslav Republic of Macedonia' 55170/00 [2006] ECHR 403.

87 See EU Parliamentary Assembly resolution at $\mathrm{n} 36$ above. 
Thus far, the arguments in favour and against the introduction of a duty of reasonable accommodation for religion or belief at work have focussed on practical issues such as the burden of proof, perceptions regarding clarity in the law, and the effect that a different framework may have on workers seeking to have a religious practice accommodated. In addition to these practical issues, there is also the question of the symbolism of the creation of a separate duty of reasonable accommodation, given that the duty does not of itself create any greater or lesser protection than that provided by indirect discrimination. The creation of a separate framework for religious interests in the workplace could be seen as granting special status to such claims, thereby privileging religion over other interests; and views will certainly differ as to whether this is a good outcome. ${ }^{88}$ However such a suggestion does presume that the special protection will be greater protection, yet as has been seen in the discussion of the USA above, there is nothing inherent in the creation of a duty of accommodation that means that this will be the case. Thus if special treatment is given to conscience claims at work, it should not necessarily be assumed to be privileging religion: if the threshold of reasonableness is set low, special treatment could just as easily lead to reduced protection.

Indeed, it may be that separate protection should be introduced for religion and belief, not because it will create stronger protection, but in order to signal clearly that religion and belief should be treated differently from other equality grounds. This is due to the risks to other areas of equality law of protecting all protected characteristics according to the same standards, as set out above. In effect creating a separate duty of reasonable accommodation would remove the danger of 'cross fertilisation' from religious discrimination claims into other areas of equality law.

\section{Conclusion}

The introduction of a duty of reasonable accommodation has been suggested as a preferred mechanism for protecting conscience claims at work by the EU Parliamentary Assembly resolution, ${ }^{89}$ the UN Special Rapporteur on freedom of religion or belief, ${ }^{90}$ and the Independent Review of the Enforcement of UK Anti-Discrimination Legislation. ${ }^{91}$ Yet, in more the recent reviews of the effectiveness of the law protecting religion and belief in UK, neither the Equality and Human Rights Commission, nor the Commission on Religion and Belief in British Public Life have taken this line. ${ }^{92}$ Instead they have concluded that the law on indirect discrimination is sufficient to deal adequately with religion or belief claims.

The main reason for this approach is their confidence that the current legal regime is largely effective in protecting religion or belief at work. Moreover, any difficulties courts or employers do face with regard to conscience claims are not overcome by a change of legal framework. Any difficulty just shifts location. For example although there is some indeterminacy in indirect discrimination when it comes to assessing whether the refusal of a request is justified, there is equally likely to be indeterminacy when a court or employer decide whether the refusal of

\footnotetext{
${ }^{88}$ See D. Pollock, Personal Memorandum n 83 above.; and G. Pitt, 'Taking religion seriously' n 80 above.

${ }^{89}$ assembly.coe.int/nw/xml/XRef/Xref-XML2HTML-en.asp?fileid=22199\&lang=en

${ }^{90}$ See also, James Orr, $\mathrm{n} 33$ above; and the EU Religare project $\mathrm{n} 35$ above.

91 B Hepple, et al. n 32 above.

92 EHRC Report Religion or belief: is the law working? (EHRC, London, 2016); Report of the Commission on Religion and Belief in British Public Life, Living with Difference: community, diversity and the common good (The Woolf Institute, Cambridge, 2015).
} 
accommodation is reasonable. Returning to the Ladele case, it does not really make any difference whether the conscience claim is cast as indirect discrimination or reasonable accommodation, or indeed, as in her ECtHR case, as a case of freedom of religion or belief, the court still has to undertake a balancing exercise and reach a considered judgement as to whether she can rely on conscientious objection to same sex relationships to be excused from a part of her job. The use of the term 'reasonable' in place of the term 'proportionate' or 'justified' does not guarantee any greater or lesser level of protection.

At least by relying on indirect discrimination to determine conscience claims in the workplace, courts will be able to draw on their long experience of assessing indirect discrimination claims. The concept of proportionality is well developed in the UK, in EU law and in the jurisprudence of the ECHR. A full assessment of how proportionality can be used to achieve a fair balance between the interests of the employers and employees cannot be given here, ${ }^{93}$ but suffice to say, the concept allows for a nuanced assessment of a wide range of factors that may arise in a case, both individualised fact sensitive matters, and broader contextual factors. Thus, by remaining within a non-discrimination framework, courts can draw on their long experience of upholding and promoting equality when assessing proportionality.

In conclusion, conscience claims in the workplace are best protected by the established law on indirect discrimination, which is sufficient to provide appropriate and balanced protection for religion and belief in the workplace. Indirect discrimination based on a the notion of proportionality offers a means to reach an equilibrium whereby individuals' protection for conscience claims at work can coexist with the rights of others.

\footnotetext{
${ }^{93}$ For more detail see L Vickers, Religious Freedom, Religious Discrimination and the Workplace $\mathrm{n} 1$ above chapter 3.
} 